\title{
Chemical Composition and Biological Activity of Ixiolirion tataricum (Pall.) Schult. \& Schult.f. var. tataricum.
}

\section{Serkan Yigitkan $\odot^{1}$, Mehmet Akdeniz ${ }^{\odot 2}$, Ismail Yener ${ }^{\oplus}{ }^{3}$, Mehmet Firat ${ }^{4}$, Kerem Senturk ${ }^{5}$, Huseyin Alkan ${ }^{6}$, Mustafa Abdullah Yılmaz ${ }^{3}$, Mehmet Ozturk ${ }^{7}$ and Abdulselam Ertas $\oplus^{3,8^{*}}$}

\author{
${ }^{I}$ Department of Pharmaceutical Botany, Faculty of Pharmacy, Dicle University, Diyarbakir, Türkiye \\ ${ }^{2}$ The Council of Forensic Medicine, Diyarbakir Group Chairmanship, Diyarbakir, Türkiye \\ ${ }^{3}$ Department of Analytical Chemistry, Faculty of Pharmacy, Dicle University, Diyarbakir, Türkiye \\ ${ }^{4}$ Department of Biology, Faculty of Education, Van Yuzuncu Yil University, Van, Türkiye \\ ${ }^{5}$ Department of Pharmaceutical Toxicology, Faculty of Pharmacy, Dicle University, Diyarbakir, \\ Türkiye \\ ${ }^{6}$ Department of Biochemistry, Faculty of Pharmacy, Dicle University, Diyarbakir, Türkiye \\ ${ }^{7}$ Department of Analytical Chemistry, Faculty of Science, Muğla Sıtkı Koçman University, Muğla, \\ Türkiye \\ ${ }^{3,8}$ Cancer Institute, Dicle University, Diyarbaktr, Türkiye
}

(Received December 08, 2021; Revised December 28, 2021; Accepted December 30, 2021)

\begin{abstract}
The role of plants in human life and the importance of plants in the food, drug and cosmetics industry have been increasing nowadays. This study investigates biological and chemical properties of root, branch, leaf, flower and aerial ethanol extracts of Ixiolirion tataricum (Pall.) Schult. \& Schult. f. var. tataricum species, consumed as food in the population. The chemical composition of the species has been determined by the LCMS/MS by specifying total phenolic and flavonoid contents. Antioxidant activity, cholinesterase, urease, tyrosinase, elastase and collagenase inhibitory activities have also been studied. According to the results of LCMS/MS, quinic acid, protocatechuic acid, $p$-coumaric acid, and rutin have been detected. The branch ethanol extract contained higher amounts of quininic acid $(12.101 \mu \mathrm{g}$ analyte/g extract) than extracts of leaves, flowers, roots and aerial parts. On the other hand, the leaves ethanol extract exhibited high antioxidant activity in all tests (ABTS: $\mathrm{IC}_{50}=57.47 \pm 0.86 \mu \mathrm{g} / \mathrm{mL}$, CUPRAC: $\mathrm{A}_{0.5}=66.76 \pm 1.86$, DPPH: $\mathrm{IC}_{50}: 119.2 \pm 1.52$ ). The species has the potential to be used in the food industry due to its high antioxidant capacity.
\end{abstract}

Keywords: Ixiolirion tataricum; LC-MS; antioxidant; enzyme activities; collagenase; elastase. (C) 2021 ACG Publications. All rights reserved.

\footnotetext{
* Corresponding author: E-mail: abdulselamertas@hotmail.com
} 


\section{Introduction}

The Amaryllidaceae family has 79 genus and about 1000 species composed of monocotyledon, flowering, bulbous plants [1]. Ixiolirion genus belonging to the Amaryllidaceae family has three perennial plant species spread in northeast Africa, middle and southwest Asia, and Egypt [2]. Ixiolirion tataricum (Pallas) Herbert subsp. montanum (Labill.) Takht. The species has been entitled the 'spring flower' in Anatolia. It has been used to strengthen memory, and it is used as an astringent in the population $[3,4]$.

Plants of the Amaryllidaceae family produce unique alkaloids with many physiologic effects, including antitumoral, antiviral, cytotoxic, anticholinesterase, immunostimulatory, anti-inflammatory analgesic and DNA binding activities, and some of which are used in the treatment of Alzheimer disease [5]. So far, there has been no study investigating the chemical composition and biological activities of I. tataricum species except for its volatile compounds. Ghalandarnejad et al. (2014) reported that the volatile oil of the aerial parts of the species extracted by hydrodistillation afforded 35 compounds. Main components are 2-phenylethyl phenylacetate $(16.8 \%), \beta$-selinen $(14.8 \%)$, bicyclovetivenol $(4.8 \%)$, thymol (4.3\%) and $(E)$-chalcone (4.3\%) [6]. In a former study published in 1988, 30 compounds, including $\alpha$-thujene, $\beta$-phellandrene, 3-carene, $\beta$-pinene, cumaldehyde, safranal, dodecyl alcohol, tetracosan, pentacosane, hexacosane, heptacosane and octacosan were reported as petroleum ether extract of I. tataricum [6,7].

Herein, leaves, branches, roots, flowers and all aerial parts of I. tataricum (Pall.) Schult. \& Schult.f. var. tataricum were dried under the shadow to prepare their ethanol extracts. The total phenolic and flavonoid composition of the species was identified, and the amounts of secondary metabolites were determined by LC-MS/MS. In addition, the antioxidant activity by ABTS, CUPRAC, and DPPH assays, and acetylcholinesterase, butyrylcholinesterase, urease, tyrosinase, elastase and collagenase inhibitory activities were also reported herein.

\section{Materials and Methods}

\subsection{Plant Material}

Roots, leaves, branches, flowers and all aerial parts of the Ixiolirion tataricum (Pall.) Schult. \& Schult.f. var. tataricum species were collected and identified by Mehmet Firat according to the Flora of Turkey, on April 2015 in Mardin [8]. Herbarium sample was kept in the herbarium of Van Yüzüncü Y11 University Science Faculty via M. Firat 32330 (VANF) herbarium number. The current valid name of the plant was also checked from the International Plant Names Index [9].

\subsection{Extraction and LC-MS/MS Analyses}

The roots, leaves, branches, flowers and aerial parts of the plants were dried under the shadow. Each studying sample was macerated with ethanol (3x8h). Briefly, 15 grams of each were weighted and extracted with $99 \%$ ethanol $(1 / 5 \mathrm{w} / \mathrm{v})$. After filtration and solvent evaporation, crude extracts were obtained.

The phytochemical quantitation of the studied extracts was performed by a previously developed and validated method [10]. The method validation parameters contains; inter-day and intraday precision (repeatability), accuracy (recovery), linearity, limits of detection and quantification $(\mathrm{LOD} / \mathrm{LOQ})$, and relative standard uncertainty $(\mathrm{U} \%$ at $95 \%$ confidence level $(\mathrm{k}=2))$. Furthermore, to increase the credibility of the results by compensating for the matrix effects and analyte losses during the sample preparation and analyses, quercetin D3, rutin D3, and ferulic acid D3 were used as the deuterated internal standards for flavonoids, flavonoid glycosides and non-flavonoid compounds, respectively.

The LC-MS/MS system used for LC-MS/MS analysis of the plant extracts was composed of Shimadzu Neexera model UHPLC device and Shimadzu LC-MS 8040 model triple quadrupole mass spectrometer device. The liquid chromatography system was composed of an LC-30 AD model gradient pump, DGU-20A3R model degasser, CTO-10ASvp model column oven and SIL-30AC model autosampler. Chromatographic separation was performed with the Inertsil ODS-4 model C18 (100 mm $\times 2,1$ 
Yigitkan et.al., Rec. Agr. Food. Chem. (2021) 1:1-2 27-34

$\mathrm{mm}, 2 \mu \mathrm{m}$ ) column. The extract was diluted to $250 \mathrm{mg} / \mathrm{L}$, and after filtration by the $0.2 \mu \mathrm{m}$ injector nozzle, the samples were located into the device [10]. The mass spectrometric detection was carried out using a Shimadzu LCMS-8040 model tandem mass spectrometer equipped with an electrospray ionization (ESI) source operating in both negative and positive ionization modes. LC-ESI-MS/MS data were acquired and processed by LabSolutions software (Shimadzu). The MRM (multiple reaction monitoring) mode was used for the quantification of the phytochemicals. The MRM metot was optimized to selectively detect and quantify phytochemical compounds based on the screening of specified precursor phytochemical-to-fragment ion transitions. The collision energies (CE) were optimized in order to generate optimal phtochemical fragmentation and maximal transmission of the desired product ions. The MS operatinging conditions were applied as: drying gas (N2) flow, $15 \mathrm{~L} / \mathrm{min}$; nebulizing gas (N2) flow, $3 \mathrm{~L} / \mathrm{min}$; DL temperature, $250{ }^{\circ} \mathrm{C}$; heat block temperature, $400{ }^{\circ} \mathrm{C}$, and interface temperature, $350^{\circ} \mathrm{C}[10]$.

\subsection{Total Flavonoid-Phenolic Content}

Total phenolic contents of the extracts were determined as pyrocatechol equivalent by using Folin-Ciocalteu reactive [11]. After preparing $100 \mathrm{ppm}$ pyrocatechol solution, 0, 1, 2, 3, 4, 5, 6, 7 ve 8 $\mu \mathrm{L}$ were taken, and they were added distillate water to complete their volumes to $184 \mu \mathrm{L}$. Ethanol extracts of the plant samples were prepared as 1000 ppm concentrate solutions. $4 \mu \mathrm{L}$ was taken from sample solutions with one-milligram extract and completed to $184 \mu \mathrm{L}$ with distillate water. $4 \mu \mathrm{L}$ FolinCiocalteu reactive (FCR) was added to pyrocatechol solutions and sample solutions, after 3 minutes 12 $\mu \mathrm{L}$ of $2 \% \mathrm{Na}_{2} \mathrm{CO} 3$ solution was also added. The final solutions were kept at room temperature for 2 hours, and the absorbance of the solution was measured at $760 \mathrm{~nm}$. Total phenolic contents of the extracts were determined by pyrocatechol equivalents from the standard pyrocatechol graphic.

Total flavonoid contents of the extracts were determined as quercetin equivalent with the aluminium nitrate method [12]. After preparation of $1000 \mathrm{ppm}$ quercetin solution, 0, 1, 2, 3, 4, 5, 6, 7 ve $8 \mu \mathrm{L}$ were taken and completed to $192 \mu \mathrm{L}$ with $80 \%$ ethanol. Four microliters of potassium acetate of $1 \mathrm{M}$ was added, and 1 minute later, four microliters of $10 \%$ aluminium nitrate were also added. After 40 minutes of incubation, the absorbances of solutions was measured at $415 \mathrm{~nm}$ by a microplate reader. The absorbance of solutions prepared from ethanol extract of samples at a fixed concentration (1000 ppm) was also read by the same method. Total flavonoid contents of the extracts were determined as quercetin equivalents using the standard quercetin graphic.

Absorbance $=0.0396+0.0217$ pyrocatechol $(\mu \mathrm{g})\left(r^{2}=0.9956\right)$

Absorbance $=0.0374+0.0456$ quercetin $(\mu \mathrm{g})\left(r^{2}=0.9965\right)$

\subsection{Antioxidant Activity}

Antioxidant activities of sample extracts were determined by DPPH free radical scavenging, ABTS cation radical scavenging and CUPRAC (cupric-reducing antioxidant capacity).

\subsubsection{DPPH (1,1-Diphenyl-2-Picrylhydrazil) Free Radical Scavenging Method}

Free radical scavenging activities of extracts were determined by using 1,1-diphenyl-2picrylhydrazil free radical [13]. Stock solutions were prepared by dissolving $10 \mathrm{mg}$ of the ethanol extracts of the samples in $10 \mathrm{ml}$ of ethanol. These stock solutions were diluted by taking 2,5,10 and 20 $\mu \mathrm{L}$ and completed to $40 \mu \mathrm{L}$ by ethanol, then $160 \mu \mathrm{L} 0.1 \mathrm{mM}$ DPPH solution was added to these four solutions. Absorbances of prepared solutions was measured at $517 \mathrm{~nm}$ after incubating the process at room temperature in the dark for 30 minutes. Inhibition (\%) values were calculated from these absorbance values. The absorbance values of the samples were compared with the control [14]. 


\subsubsection{ABTS Cation Radical Scavenging Activity}

ABTS cation radical scavenging activities of extracts were determined by using $2,2^{\prime}$-azinobis(3-ethylbenzothiazoline-6-sülfonic acid) [15].

Stock solutions were prepared by dissolving $10 \mathrm{mg}$ of the ethanol extracts of the samples in 10 $\mathrm{ml}$ of ethanol. These stock solutions were diluted by taking $2,5,10$ and $20 \mu \mathrm{L}$ and completed to $40 \mu \mathrm{L}$ by ethanol, then $160 \mu \mathrm{L} 7 \mathrm{mM}$ ABTS cation radical solution was added to these four solutions. Absorbances of prepared solutions was measured at $734 \mathrm{~nm}$ after waiting for 6 minutes in the dark. The absorbance values of the samples were compared with the control.

\subsubsection{CUPRAC (Cupric-reducing Antioxidant Capacity) Method}

In the CUPRAC method, in the presence of antioxidant compounds in the samples, the $\mathrm{Cu}(\mathrm{II})$ Neocuproin $(\mathrm{Nc})$ complex is reduced to coloured $\mathrm{Cu}(\mathrm{I})-\mathrm{Nc}$ chelate and the absorbance of this chelate is measured at $450 \mathrm{~nm}$. Cu (II), neokuproin and $\mathrm{NH}_{4} \mathrm{Oac}$ buffer were added to the prepared samples and standards as the final concentrations $10,25,50,100 \mu \mathrm{g} / \mathrm{mL}$. One hour later, absorbances were measured at $450 \mathrm{~nm}$ [16]. The absorbance values of the samples were compared with the control. Three parallel studies were performed in all three methods. BHT and $\alpha$-Toc were used as positive standards.

\subsection{Anticholinesterase Activity}

Acetylcholinesterase (AChE) and butyrylcholinesterase inhibitory activities were measured based on the spectrophotometric method reported by Ellman et al. [17]. Acetylcholinesterase from electric fish and butyrylcholinesterase from horse serum were used as enzymes. Acetylcholine iodide and butyrylcholin iodide were acted as substrates, while yellow 5,5'-dithiobis-(2-nitrobenzoic acid) (DTNB) was used to measure activity. To each well of 96-well microplates $130 \mu \mathrm{L} 0,1 \mathrm{M} \mathrm{pH}=8$ phosphate buffer, $10 \mu \mathrm{L}$ sample, and $20 \mu \mathrm{L} \mathrm{AChE}$ or BChE enzymes were added and incubated at 25 ${ }^{\circ} \mathrm{C}$ for 10 minutes. Finally, $20 \mu \mathrm{L}$ DTNB solution and $20 \mu \mathrm{L}$ acetylcholine iodide or butyrylcholin iodide were added, respectively. The yellow 5-thio-2-nitrobenzoic acid formed as a result of the reaction of thiocholin, released by the enzymatic hydrolysis of acetylcholine iodide or butyrylcholin iodide, and DTNB was monitored spectrophotometrically at $412 \mathrm{~nm}$ wavelength. Ethanol was used as control, and galanthamine was used positive standard to compare the activity [18].

\subsection{Urease Inhibitory Activity}

For the urease inhibition activity, urease was used as an enzyme. Ten microliters of sample solution prepared at $4000 \mathrm{ppm}$ concentration in ethanol, $25 \mu \mathrm{L}$ of enzyme solution in buffer, and $50 \mu \mathrm{L}$ of urea as substrate were added to the microplate wells. The first absorbance was first was read at 630 $\mathrm{nm}$. Then this solution was incubated at $30^{\circ} \mathrm{C}$ for 15 minutes. After 15 minutes, $45 \mu \mathrm{L}$ phenol reagent and $0 \mu \mathrm{L}$ alkaline reagent were added. It was incubated at $30^{\circ} \mathrm{C}$ again, and after 20 minutes, the microplate was placed in an ELISA reader, and the final absorbance was read at $630 \mathrm{~nm}$ wavelength. Thiourea was used as a positive standard $[19,20]$.

\subsection{Anti-aging Inhibitory Activity}

Tyrosinase, elastase and collagenase inhibitory activity methods were used to determine the anti-ageing potential of the extracts. The technique improved by Hearing and Jimenez [21] was used with slight changes for the tyrosinase inhibitory activity. Kojic acid was used as a positive standard. For the elastase inhibitory activity, the reported method by Kraunsoe et al. (1996) [22] was applied to the extracts with slight changes. Oleanolic acid was used as a positive standard. For the collagenase inhibitory activity, however, the protocol improved by Thring et al. (2009) [23] was applied to extracts with slight modifications. Epicatechin gallate was used as a positive standard herein [24,25].

The following equation was used to calculate the inhibitory activities of acetylcholinesterase (AChE), butyrylcholinesterase (BChE), urease, tyrosinase, elastase, and collagenase. In all enzyme inhibitory assays, percentage (\%) values were calculated at $100 \mu \mathrm{g} / \mathrm{mL}$ of three parallel measurements Enzyme inhibition $(\%)=100-(\mathrm{OD}$ test well $/ \mathrm{OD}$ control $) \times 100$ 


\section{Results and Discussion}

Root, leaf, branch, flower and aerial parts of I. tataricum species extract's phenolic composition was determined by LC-MS/MS. According to the LC-MS/MS results, quinic acid, protocatechuic acid, p-coumaric acid and rutin content of this species were determined. According to the LC-MS/MS results, the branches ethanol extract contains the highest amount of quinic acid than the all aerial parts, roots, leaves and flowers $(12.101,5.809,3.642,3.421,7.452 \mu \mathrm{g}$ analyte/g extract, respectively) extracts. Additionally, while protocatechuic acid was not found in this species root and branch extracts, the leaf, flower and aerial parts extracts $(0.229,0.223,0.14 \mu \mathrm{g}$ analyte/g extract, respectively), existed. $p$ Coumaric acid was only detected and quantified in leaves and flowers $(0.064,0.189 \mu \mathrm{g}$, respectively). Rutin was only determined in flowers extract $(0.299 \mu \mathrm{g}$ analyte/g extract) (Table 1$)$.

Total phenolic and flavonoid contents of the ethanol extracts of the species were determined to be equivalent to pyrocatechol and quercetin, respectively (Table 2). The results determined that phenolic and flavonoid contents of the leaves ethanol extract were higher than the other parts of the plant.

According to the antioxidant activity of ethanol extracts via three complementary assays. The leaves extract exhibited very high antioxidant activity (ABTS: $\mathrm{IC}_{50}=57.47 \pm 0.86$, CUPRAC: $\mathrm{A}_{0.5}=$ $66.76 \pm 1.86$, DPPH: $\mathrm{IC}_{50}=119.20 \pm 1.52 \mu \mathrm{g} / \mathrm{mL}$ ) when compared to the other part extracts. In the studied enzyme inhibition experiments, it has been determined that $I$. tataricum showed low enzyme inhibition activity (Table 2).

Only two studies exist about the chemical and biological activity studies of I. tataricum species in the literature. These two studies are about only the essential oil content of the species. Likewise, there are no studies in the literature except ethnobotanical and morphological studies of other species of the Ixiolirion genus $[3,26]$.

Table 1. Identification and quantification of phenolic compounds of ethanol extracts of I. tataricum by LC-MS/MS

\begin{tabular}{|c|c|c|c|c|c|c|c|c|}
\hline \multirow[b]{2}{*}{ No } & \multirow[b]{2}{*}{ Analytes } & \multirow{2}{*}{$\begin{array}{c}\text { Parent } \\
\operatorname{ion}(\mathbf{m} / \mathbf{z}) \\
a\end{array}$} & \multirow{2}{*}{$\begin{array}{c}\text { MS }^{2} \\
\text { (Collision } \\
\text { Energy) }^{\mathbf{b}}\end{array}$} & \multicolumn{5}{|c|}{ Quantification ( $\mu$ g analyte/g extract) } \\
\hline & & & & IT-B & IT-M & IT-R & IT-L & IT-F \\
\hline 1 & Quinic acid & 190.8 & 93.0 & 12,101 & 5,809 & 3,642 & 3,421 & 7,452 \\
\hline 24 & $p$-Coumaric acid & 163.0 & 93.0 & N.D ${ }^{d}$ & N.D & N.D & 0,064 & 0,189 \\
\hline 33 & Rutin & 608.9 & 301.0 & N.D. & N.D. & N.D. & N.D. & 0,299 \\
\hline 35 & Hesperidin & 611.2 & 449.0 & N.D & N.D & N.D & N.D & 0,29 \\
\hline 48 & Naringenin & 270.9 & 119.0 & N.D & N.D & N.D & 0,019 & N.D \\
\hline 50 & Luteolin & 284.8 & $151.0 / 175.0$ & N.D & 0,055 & N.D & 0,027 & 0,005 \\
\hline 51 & Genistein & 269.0 & 135.0 & N.D & N.D & N.D & N.D & N.D \\
\hline 52 & Kaempferol & 285.0 & 239.0 & N.D & 0,013 & 0,007 & 0,012 & 0,013 \\
\hline 53 & Apigenin & 268.8 & $151.0 / 149.0$ & 0,004 & 0,007 & 0,002 & 0,018 & 0,004 \\
\hline
\end{tabular}

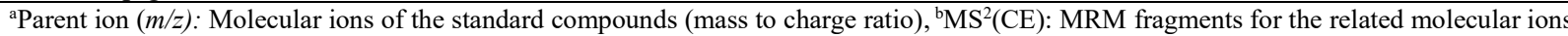
(CE refers to related collision energies of the fragment ions), ${ }^{\mathrm{c}}$ Values in $\mu \mathrm{g} / \mathrm{g}$ (w/w) of plant ethanol extract, ${ }^{\mathrm{d}} \mathrm{N} . \mathrm{D}$ : not detected.

Undetected components, 2: Fumaric acid. 3: Aconitic acid. 4: Gallic acid. 5: Epigallocatechin. 6: Protocatechuic acid. 7: Catechin. 8: Gentisic acid. 9: Chlorogenic acid. 10: 10 Protocatechuic aldehyde. 11: Tannic acid. 12: Epigallocatechin gallate. 13: 1,5-Dicaffeoylquinic acid. 14: 4$\mathrm{OH}$ Benzoic acid. 15: Epicatechin. 16: Vanilic acid. 17: Caffeic acid. 18: Syringic acid. 19: Vanillin. 20: Syringic aldehyde 21: Daidzin 22: Epicatechin gallate. 23: Piceid. 25: Ferulic acid-D3-IS. 26: Ferulic acid. 27: Sinapic acid. 28: Coumarin. 29: Salicylic acid. 30: Cynaroside. 31: Miquelianin. 32: Rutin-D3-IS. 34: isoquercitrin. 36: o- Coumaric acid. 37: Genistin. 38: Rosmarinic acid. 39: Ellagic acid. 40: Cosmosiin. 41: Quercitrin. 42: Astragalin. 43: Nicotiflorin. 44: Fisetin. 45: Daidzein. 46: Quercetin-D3-IS: 47: Quercetin. 49: Hesperetin. 54: Amentoflavone. 55: Chrysin. 56: Acacetin. 
Table 2. Total phenolic-flavonoid content, antioxidant and biological activities of the $I$. tataricum extracts ${ }^{\text {a }}$

\begin{tabular}{|c|c|c|c|c|c|c|c|c|c|c|c|}
\hline \multirow{3}{*}{ Samples ${ }^{b}$} & \multirow{3}{*}{$\begin{array}{c}\text { Total } \\
\text { phenolic } \\
(\mu \mathrm{g} \\
\text { PEs/mg })^{\mathrm{d}}\end{array}$} & \multirow{3}{*}{$\begin{array}{c}\text { Total } \\
\text { flavonoids } \\
(\mu \mathrm{g} \\
\text { QEs/mg) }\end{array}$} & \multicolumn{3}{|c|}{ Antioxidant activity } & \multicolumn{6}{|c|}{ Enzyme inhibitory activity } \\
\hline & & & \multirow{2}{*}{$\begin{array}{c}\begin{array}{c}\text { IC } \\
(\mu 0 \\
(\mu \mathrm{g} / \mathrm{mL})\end{array} \\
\text { DPPH } \\
\text { assay }\end{array}$} & \multirow{2}{*}{$\begin{array}{c}\begin{array}{c}\text { IC50 } \\
(\mu \mathrm{g} / \mathrm{mL})\end{array} \\
\text { ABTS } \\
\text { assay }\end{array}$} & \multirow{2}{*}{$\begin{array}{c}\left(\mathrm{A}_{0.5}\right) \\
(\mu \mathrm{g} / \mathrm{mL}) \\
\text { CUPRAC } \\
\text { assay }\end{array}$} & \multicolumn{6}{|c|}{ Inhibition $(\%)$ at $100 \mu \mathrm{g} / \mathrm{mL}$} \\
\hline & & & & & & $\begin{array}{c}\text { AChE } \\
\text { assay }\end{array}$ & $\begin{array}{l}\text { BChE } \\
\text { assay }\end{array}$ & $\begin{array}{c}\text { Urease } \\
\text { assay }\end{array}$ & $\begin{array}{c}\text { Tyrosinase } \\
\text { assay }\end{array}$ & $\begin{array}{c}\text { Elastase } \\
\text { assay }\end{array}$ & $\begin{array}{c}\text { Collagenase } \\
\text { assay }\end{array}$ \\
\hline IT-R & $10.05 \pm 0.35$ & $2.58 \pm 0.72$ & $>1000$ & $240.1 \pm 1.35$ & $217.3 \pm 1.24$ & $N A$ & $N A$ & $N A$ & $N A$ & $4.21 \pm 0.68$ & $N A$ \\
\hline IT-B & $14.55 \pm 1.29$ & $3.47 \pm 0.63$ & $509.1 \pm 4.21$ & $71.42 \pm 1.58$ & $135.1 \pm 1.55$ & $N A$ & $N A$ & $N A$ & $N A$ & $3.53 \pm 0.36$ & $4.08 \pm 0.24$ \\
\hline IT-L & $52.47 \pm 1.96$ & $16.84 \pm 1.31$ & $119.2 \pm 1.52$ & $57.47 \pm 0.86$ & $66.76 \pm 1.86$ & $N A$ & NA & $N A$ & $N A$ & $N A$ & $2.46 \pm 0.19$ \\
\hline IT-F & $18.25 \pm 1.06$ & $4.54 \pm 0.44$ & $166.6 \pm 1.39$ & $62.50 \pm 1.19$ & $87.71 \pm 0.95$ & NA & $N A$ & NA & $9.42 \pm 1.08$ & $N A$ & $6.81 \pm 1.23$ \\
\hline IT-M & $23.68 \pm 1.60$ & $7.92 \pm 1.39$ & $160.2 \pm 1.61$ & $60.12 \pm 0.67$ & $106.8 \pm 1.95$ & $N A$ & $N A$ & $N A$ & $1.31 \pm 0.82$ & $N A$ & $N A$ \\
\hline $\mathrm{BHT}^{\mathrm{c}}$ & - & - & $54.12 \pm 1.33$ & $13.77 \pm 0.13$ & $8.24 \pm 0.09$ & - & - & - & - & - & - \\
\hline$\alpha-$ TOC $^{c}$ & - & - & $16.43 \pm 0.24$ & $9.88 \pm 0.34$ & $18.27 \pm 0.67$ & - & - & - & - & - & - \\
\hline $\begin{array}{l}\text { Galanthamine } \\
\mathrm{c}\end{array}$ & - & - & - & - & - & $94.46 \pm 1.22$ & $77.21 \pm 0.48$ & - & - & - & - \\
\hline Thiourea $^{c}$ & - & - & - & - & - & - & - & $99.73 \pm 0.13$ & - & - & - \\
\hline Kojic acid $^{c}$ & - & - & - & - & - & - & - & - & $74.26 \pm 1.25$ & - & - \\
\hline $\begin{array}{l}\text { Oleanolic acid } \\
\mathrm{c}\end{array}$ & - & - & - & - & - & - & - & - & - & $60.28 \pm 0.50$ & \\
\hline $\begin{array}{l}\text { Epicatechin } \\
\text { gallate }^{\mathrm{c}}\end{array}$ & - & - & - & - & - & - & - & - & - & - & $71.77 \pm 1.22$ \\
\hline
\end{tabular}




\section{Conclusion}

The chemical composition of ethanol extracts of I. tataricum species has been determined by LCMS/MS. The total phenolic and flavonoid amount, antioxidant capacity and biological activities of the samples of the species have been investigated for the first time in this study. It has been determined that leaf extract shows high antioxidant features so that the species can be considered in the food industry as a food preservative. However, further studies especially, cytotoxic and in vivo studies, should be performed to concise the commentary.

\section{ORCID}

Serkan Yigitkan: 0000-0002-6202-1515

Mehmet Akdeniz: 0000-0002-4435-4826

Ismail Yener: 0000-0002-0988-9462

Mehmet Firat: 0000-0001-5814-614X

Kerem Senturk: 0000-0002-1494-8260

Huseyin Alkan: 0000-0002-0761-6436

Mustafa Abdullah Y1lmaz: 0000-0002-4090-7227

Mehmet Ozturk: 0000-0001-8932-4535

Abdulselam Ertas: $\underline{\text { 0000-0002-2193-8386 }}$

\section{References}

[1] J.J. Nair and J.V. Staden (2013). Pharmacological and toxicological insights to the South Africa Amaryllidaceae, Food Chem. Toxicol. 62, 262-275.

[2] Y. Li, F. Song, X.N. Zhang, G.H. Lv (2019). Phylogeography suggest the Yili Valley being the glacial refuge of the genus Ixiolirion (Amaryllidaceae) in China, System. Biodivers. 17(4), 1-17.

[3] U. Cakilcioglu, S. Khatun, I. Turkoglu, S. Hayta (2011). Ethnopharmacological survey of medicinal plants in Maden (Elazig-Turkey), J. Ethnopharmacol. 137, 1, 469-486.

[4] B. Farzan, S. Abbaszadeh, G. Basati, H. Teimouri (2019). An overview of the most important medicinal plants effective on the strength of memory and mind in Iranian ethnobotany, J. Pharm. Pharmacogn. Res. 7, 3, 156-162.

[5] E. J. Osorio, S. Berkov, R. Brun, C. Codina, F. Viladomat, F. Cabezas, J. Bastida (2010). In vitro antiprotozoal activity of alkaloids from Phaedranassa dubia (Amaryllidaceae), Phytochem. Lett. 3, 3, 161-163.

[6] M. Ghalandarnejad1, M.R. Akhgar, P. Rajaei (2014). Chemical composition of the essential oil from the aerial parts of Ixiolirion tataricum (Pall.) Herb., Int. J. Adv. Biol. Biomed. Res. 2, 1, 105-109.

[7] J. Yong, and S. Jieying (1988). A study on chemical composition of Ixiolirion tataricum (Pall.) Herb., J. Aug. First. Agr. Coll. 11, 81-84.

[8] P. H. Davis (1984) Flora of Turkey and the East Aegean Islands, vol. 8. Edinburgh University Press, Edinburgh.

[9] IPNI (2021). International Plant Names Index. Published on the Internet http://www.ipni.org, The Royal Botanic Gardens, Kew, Harvard University Herbaria \& Libraries and Australian National Botanic Gardens. [Accessed 14 December 2021].

[10] M. A. Yilmaz (2020). Simultaneous quantitative screening of 53 phytochemicals in 33 medicinal and aromatic plants species: A detailed, robust and comprehensive LC-MS/MS method validation, Ind. Crops. Prod. 149, 112347.

[11] K. Slinkard, V.L. Singleton (1977). Total phenol analyses: Automation and comparison with manual methods, Am. J. Enol. Viticult. 28, 49-55.

[12] M. I. N. Moreno, M. I. Isla, , A.R. Sampietro, M.A. Vattuone (2000). Comparison of the free radicalscavenging activity of propolis from several regions of Argentina, J. Ethnopharmacol. 71, 109-114.

[13] M.S. Blois, (1958). Antioxidant determinations by the use of a stable free radical, Nature 181, 1199-1200.

[14] E. Izol, H. Temel, M. A. Yilmaz, I. Yener, O. Tokul-Olmez, E. Kaplaner, M. Firat, N. Hasimi, M. Ozturk, A. Ertas, (2021), A detailed chemical and biological investigation of twelve Allium species from Eastern Anatolia with chemometric studies, Chem. Biodivers. 18, e2000560.

[15] R. Re, N. Pellegrini, A. Proteggente, A. Pannala, M. Yang, C. Rice-Evans (1999). Antioxidant activity applying an improved ABTS radical cation decolorization assay, Free Radical Bio. Med. 26, 1231-1237. 


\section{Chemical composition and biological activity of Ixiolirion tataricum}

[16] R. Apak, K. Guclu, M. Ozyurek, S. E. Karademir (2004). Novel total antioxidant capacity index for dietary polyphenols and vitamins $\mathrm{C}$ and $\mathrm{E}$ using their cupric ion reducing capability in the presence of neocuproine: CUPRAC Method, J. Agr. Food Chem. 52, 7970-7981.

[17] G. L. Ellman, K. D. Courtney, V. Andres, R. M. Featherstone (1961). A new and rapid colorimetric determination of acetylcholinesterase activity, Biochem. Pharmacol. 7, 88-95.

[18] I. Yener, S.O. Kocakaya, A. Ertas, B. Erhan, E. Kaplaner, E.V. Oral, T. Yilmaz-Ozden, M.A. Yilmaz, M. Ozturk, U. Kolak (2020). Selective in vitro and in silico enzymes inhibitory activities of phenolic acids and flavonoids of food plants: Relations with oxidative stress, Food Chem. 15, 327, 127045.

[19] Z. Hina, H. R. Ghazala, K. Arfa, S. Huma, T. Sabiha, K. Ajmal (2015). Anti-urease activity of Mimusops elengi Linn (Sapotaceae), European J. Med. Plants. 6, 223-230.

[20] A. Ertas, M. Firat, I. Yener, M. Akdeniz, S. Yigitkan, D. Bakir, C. Çakır, M. A. Yilmaz, M. Ozturk, U. Kolak (2021). Phytochemical fingerprints and bioactivities of ripe disseminules (Fruit-Seeds) of seventeen Gundelia (Kenger-kereng dikeni) species from Anatolia with chemometric approach, Chem. Biodivers. 18, e2100207.

[21] V.J. Hearing, M. Jiménez (1987). Mammalian tyrosinase the critical regulatory control point in melanocyte pigmentation, Int. J. Biochem. 19, 1141-1147.

[22] J.A.E. Kraunsoe, T.D.W. Claridge, G. Lowe (1996). Inhibition of human leukocyte and porcine pancreatic elastase by homologues of bovine pancreatic trypsin inhibitor, Biochem. 35, 9090-9096.

[23] T.S.A. Thring, P. Hili, Declan, D.P. Naughton (2009). Anti-collagenase, anti-elastase and anti-oxidant activities of extracts from 21 plants, BMC Complement, Altern. Med. 9, 1-11.

[24] M. Akdeniz, I. Yener, M.A. Yilmaz, S.I. Kandemir, F. Tekin, A. Ertas (2021). A potential species for cosmetic and pharmaceutical industries: Insight to chemical and biological investigation of naturally grown and cultivated Salvia multicaulis Vahl., Ind. Crops Prod. 168, 113566.

[25] E.A. Tilkat, H. Batibay, I. Yener, P. K. Yilmaz, M. Akdeniz, V. Holubec, A. Kaplan, S. Ercisli, A. Ertas, (2021). Determination of antihypertensive, anticholinesterase, antiurease, antityrosinase, antielastase enzyme inhibition and anticancer effects of Pistacia khinjuk Stocks raised in in vitro and in vivo conditions, Argon 11, 1, 154.

[26] Y. Zhao, Y. Li, Y. Liu, Y.F. Yang (2015). DNA barcoding for efficient identification of Ixiolirion species (Ixioliriaceae), Genet. Mol. Res. 14, 1903-1910.

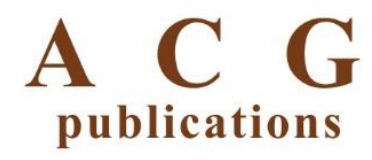

(C) 2021 ACG Publications 